\title{
Unamuno y ell problema de la identidad hispanoamericana
}

\author{
Raimundo Prado Redondez \\ Departamento Académico de Filosofía
}

\begin{abstract}
T a lectura integral de las obras más representativas de los diferentes momentos de la biografía intelectual de don Miguel de Unamuno, nos permite descubrir un aspecto fecundo y vigente de su pensamiento vital: la esperanza agónica de la constitución de una nueva identidad hispánica, superadora dialéctica de España y América española.
\end{abstract}

Algunos aspectos de esta nueva propuesta identitaria, pensada y sentida bajo el término de "hispanidad" acunado por Unamuno, han sido compartidos con algunos intelectuales de la generación del 98; especialmente con Angel Ganivet. Indudablemente, esta generación no sólo constituye ia más lúcida conciencia crítica deProceso hiśricolespariot, sino -sobre todo- la valiosa gestación de un ideal șuperiop de régerièración yecreación de una nueva patria española.

Complejas fuerzas y circunstancias históricas posibilitaron la gestación de este nuevo proyecto de identidad. Sin duda, el catalizador más importante fue la pérdida de las últimas colonias españolas: Cuba y Filipinas.

En el presente trabajo, de un modo sumario, sólo queremos mostrar los aspectos y supuestos más importantes que presenta la concepción unamuniana de una nueva identidad hispanoamericana. Pero, previamente, es conveniente que señalemos algunas condiciones decisivas que, a nuestro juicio, posibilitan una mejor comprensión de su idea básica como es la idea de "hispanidad". Consideramos que son las siguientes: su clave metodológica, la experiencia

Letras (Lima), 99-100, 2000: 111-115 
de América y su pertinente revisión histórica y las tensiones dialécticas de su pensamiento.

\section{La clave metodológica}

La comprensión, la más aproximada posible, de la auténtica posición de Unamuno sobre el tópico que nos concierne, depende de la adecuada inteligencia de su clave metodológica. Sería un grave error no tomar en cuenta la radicalidad dialéctica de los extremos de su modo de pensar. Se trata de una perspectiva dramáticamente consciente de los abismos de la realidad y de la vida. Directamente, nuestro autor describe de la siguiente manera su método consistente en un "proceso de vaivén de hipérbole" o de "procedimiento rítmico de contradicciones":

Me conviene también prevenir a todo lector respecto a las afirmaciones cortantes y secas que aquí leerá y a las contradicciones que le parecerá hallar. Suele buscarse la verdad completa en el justo medio por el método de remoción, via remotionis, por exclusión de los extremos, que con su juego de acción mutua engendran el ritmo de la vida, y así sólo se llega a la sombra de verdad, fría y nebulosa. Es preferible, creo, seguir otro método: el de afirmación alternativa de los contradictorios; es preferible hacer resaltar la fuerza de los extremos en el alma del lector para que el medio tome en ella vida, que es resultante de lucha. Tenga, pues, paciencia cuando el ritmo de nuestras reflexiones tuerza a un lado, y espere a que en su ondulación tuerza al otro y deje se produzca así en su ánimo la resultante, si es que lo logro ${ }^{1}$.

No es que Unamuno excluya el "justo medio" sino exige una elucidación más omnicomprensiva. El "justo medio", como anota, es resultado de lucha de fuerzas contrastantes. Por esta circunstancia, la intelección de los extremos permite la comprensión del ritmo global de la historia. De otro modo, partiéndose del justo medio sólo se verá y se construirá una historia abstracta e hipostasiada de la realidad.

Miguel de Unamuno. En torno al casticismo. En José Luis Aranguren. Antología. México,

Fondo de Cultura Económica, p. 111. 
Llama la atención que dos autores contemporáneos, el italiano Piero Gobetti y el peruano José Carlos Mariátegui, hayan tenido la misma idea metodológica. Así, Gobetti afirma que "el verdadero realismo tiene el culto de las fuerzas que crean los resultados, no la admiración de los resultados intelectualísticamente contemplados a priori. El realista sabe que la historia es un reformismo, pero también que el proceso reformístico, en vez de reducirse a una diplomacia de iniciados, es producto de los individuos en cuanto operen como revolucionarios, a través de netas afirmaciones de contrastantes exigencias" 2 .

\section{Por los caminos de América, Unamuno descubre España}

No es exagerado afirmar que Unamuno descubrió España por la mediación de un amplio y profundo conocimiento de Hispanoamérica. Así lo prueban los trabajos mejor documentados ${ }^{3}$.

Aunque Unamuno físicamente nunca estuvo en América, logró tener una información viva a travês de libros americanos, correspondencia con intelectuales de diferentes filiáciones ideológicas y contactos personales con hombres de cultura hispanoamericanos. Desde temprano descubrió la "españolía" del libro americano expresada en la lengua común, la lengua castellana. Juzgó históricamente necesarią la españolización dei castellano.

Reiteramos, la profunda compenetracion con la cultura hispanoindia, le permitió a Unamuno descubrir el fondo común trascendente encubierta por la historia sonora y atropellada de los hechos políticos. Consideró, por ejemplo, la llamada guerra de la independencia como una guerra civil entre españoles.

En suma, el célebre maestro salmantino hizo toda una revaloración integral del proceso histórico-cultural iberoamericano, la que constituirá un

2 José Carlos Mariátegui. 7 ensayos..., 1992, p. 229.

3 Es imperativo mencionar dos trabajos estupendamente documentados sobre la vinculación de Unamuno con América hispano-inđia:

1) Julio César Chaves. Unamuno y América. Madrid, Editorial Cultura Hispánica, 1964.

2) Manuel García Blanco. América y Unamuno. Madrid, Gredos, 1964. 
aspecto fecundo de su nueva esperanza resumida y expresada con la palabra "hispanidad", patria grande y común de los pueblos hispánicos (españoles e hispanoindianos).

\section{Tensiones dialéctica en la biografía intelectual de Unamuno}

Hay una transparencia excepcional en la escritura unamuniana, la que depende de una relación de autenticidad entre el sentimiento y el pensamiento. En Unamuno, según sus propias palabras, "piensa el sentimiento, siente el pensamiento". Una vida intelectual con estas características se muestra con todas sus transiciones y tensiones dialécticas. Incluso, esta experiencia dialéctica es transformada, como hemos visto, en recurso metodológico.

Unamuno es trágicamente consciente de las tensiones de su vida intelectual. Su ritmo profundo, armonioso y polifónico, sólo es descubrible y determinable atendiendo a las fuerzas que antagonizan y se reclaman en su pensamiento.

Para mostrar este aspecto, nos bastaría señalar los pares dialécticos que tuercen la mirada unamuniana: razón-fe, vacío-plenitud, continente-contenido, historia-intrahistoria, civilización-cultura, siglos-hora, conservación-perpetuación, simple-complejo, imposicióntresistenciąexterioridad-interioridad, individuo-persona, nągiónguebleclp económicelooreligioso, etc.

De los pares dialécticos, Unamuno privilegia los polos que figuran en segundo lugar en la relación que acabamos de presentarla. De este modo, la "fe", en contraste con la razón es dadora de sentido y creadora (creer es crear); la "intra-historia", a diferencia de la historia atropellada de hechos políticos, es la dimensión profunda, continua y silenciosa de un pueblo; el "pueblo" es abertura a la humanidad, la nación es obliteración; "lo complejo" es rico y polifónico, lo simple es lo pobre y homofónico, etc. Por esta razón, nuestro pensador-sentidor, funda su idea de "hispanidad" en estas dimensiones profundas y no en los elementos diferenciales circunstanciales e intrascendentes. 
Atendiendo a los extremos contradictorios en la biografía intelectual de Unamuno, encontramos el "justo medio" de su posición que se condensa y expresa en la palabra "hispanidad". Estos polos contradictorios se cristalizan en las exigencias de "europeización de España" (demanda de modernización socializante) y de la "españolización de Europa" (exigencia de insuflar un sentido de trascendencia a la Europa moderna con los elementos de religiosidad o de quijotismo propio del pueblo español) $)^{4}$.

Evidentemente, la "hispanidad" es pensada como el fondo común, como la patria universal de naturaleza cultural. La configuración de esta esperanza de una comunidad espiritual, abarcadora de todos los pueblos hispánicos (indianos y españoles) se muestra mejor con la visualización de sus elementos constitutivos: se trata de una unidad conformada por una "variedad íntima" o como "integración de diferencias"; se nutre de la tradición siempre renovada; es compleja, condición que posibilita su riqueza y capacidad creadora; es abierta, por tanto capaz de apropiarse y asimilar cualquier creación humana; es basada en la "intra-historia" y en la lengua común, la lengua de Quijote -lengua que no sólo contiene una peculiar "visión" sino, también, una determinada "audición" del mundos es "polifónica" porque es acorde de los discordancias. Esta idea de "hispanidad" no sólo exige el reconocimiento de las diferencias cualitativas de los pueblos sino demanda el protagonismo y mutuas

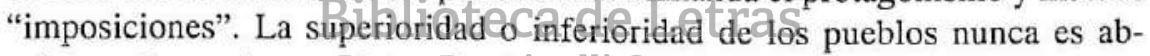

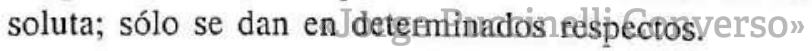

En conclusión, esta nueva identidad, expresada por Unamuno como un "nuevo patriotismo", está pensada y sentida como grande, rica, variada y compleja. Es sueño de plenitud humana: "plenitud de plenitudes".

4 Dos obras de Unamuno, a nuestro juicio, las transiciones dialécticas de su posición: En torno al casticismo (1895) contiene la exigencia de "europeización" de España y Vida de don Quijote y Sancho (1905) la necesidad de "españolización" de Europa. 